\title{
Chapter 9 \\ Cultural and Media Identity Among \\ Latvian Migrants in Germany
}

\author{
Laura Sūna
}

\subsection{Introduction}

In times of increasing migration, migrant attachment to the country of origin is often seen as negative in the society. These discourses speak about migrants forming a parallel society; of the cultural separation of migrants, and other similar issues. Media - and especially digital media - is seen as an important tool for enabling the continuation of practices maintaining the attachment of migrants to their homeland. Research on this issue has shown that such polarisation does not correspond to the reality (Akşen 2013; Bozdağ 2013; Hepp et al. 2012). Rather, this research indicates that migrants have hybrid identities and rarely speak about a cultural alienation from their country of residence. In their everyday lives migrants are confronted with questions of cultural proximity and distance in their immediate physical environments. Diverse references to the country of origin and its integration into the context of the land of residence is an everyday practice for them. Georgiou (2012, p. 871) describes this migrant reality as 'being with distant others without being in distant places'.

This chapter seeks to describe the identity negotiation of migrants, and explore how transnational media and culture impacts the identity formation of recent Latvian-origin migrants in Germany. How do Latvian migrants in Germany feel and experience their belonging to Latvia and its culture? Do certain social and communicative practices foster this sense of belonging, while others hinder it? How deeply rooted are they in the country they live in and which cultural references are important for them? These are questions the chapter will answer based on qualitative data (interviews, network maps, media diaries) gained from the Latvian diaspora in Germany. Factors considered in this analysis include the importance of Latvian

L. Sūna $(\varangle)$

Institute for Media and Communication Studies, Freie Universität Berlin, Berlin, Germany e-mail: laura.suna@fu-berlin.de 
traditional culture, in particular the culture of 'the choir' and of singing (Tisenkopfs et al. 2008). The cultural policy of the Republic of Latvia in trying to re-connect with migrants abroad using traditional and popular Latvian culture will be considered.

This chapter will first discuss the theoretical concept of cultural identity and describe the role of culture and media in the process of building an identity. Information about the Latvian diaspora in Germany is provided in the second section, followed by a description of the research design of this study. In subsequent sections the author argues that culture is shaping the transnational self-perception of migrants, as it provides collective narratives of imagined common frames of references and confirms processes of cultural belonging and distinction.

\subsection{Cultural Identity, Culture and Media}

Culture - and music in particular - can be seen as a symbolic resource of modern individuals, as it is omnipresent in different contexts and forms a soundscape of the everyday for them (Bennett 2005, p. 118). Cultural identity is defined in this chapter from the perspective of cultural studies and symbolic interactionism. All in all, identity is seen as an on-going identification process (Hall 1994). This means that identities develop first in the interaction between the 'self' and the 'society' (Krotz 2003). Secondly, according to Stuart Hall's (1994) theory of articulation, individuals rely on different discourses and meaning horizons in different contexts. Instead of defining identity as finalised, in the context of individualisation (Beck 1986) and mediatisation (Hjarvard 2008) it is more common to define identity as an on-going process of articulation, that is fulfilled as a communicative and contextual distinction towards different identification offers (Hepp et al. 2012). These are mediatised on different levels and rely on plural cultural contexts. In the following sections the concept 'identity' is used not in an essentialist sense as something static but rather in the sense of it being an on-going process of the articulation of elements from different discourses. These might be national, ethnic, regional, religious, diasporic, pop-cultural or other (Hepp 2015, p. 226). Hall (1994) speaks in this context of hybrid cultural identities that rely on different discourses that are a result of the active 'identity work' of the individual. The hybrid identities change the 'either... or' perspective of the modern subject to the 'as well as' perspective (Hugger 2007, p. 175). This replaces the 'excluding perspective' - where only one, dominant identity reference is possible - with a new more inclusive perspective, involving an acceptance of different aspects of identity. Identity can rely on different apparently opposing cultural references and negotiates them in a hybridity. Hybridity is a particular characteristic of migrant identities as migrants absorb cultural contexts not only from the local country of residence but also from their country of origin and other transnational contexts (Bozdağ 2013). However, this phenomenon is not exclusive only to migrants. Besides migrant communities, the identities of other social groups can be seen as hybrid as well: adolescents, for example, go through similar processes (Hitzler and Niederbacher 2010; Sūna 2013; Vogelgesang 2006). 
The construction of cultural identity, therefore, is a continuous balance. On the one hand, there is the individual's sense of self: as constructed by them and located between self-perception and their identification, possibly at various degrees, with different discourses. On the other hand, and possibly varying from one communication situation to another, is the ascription of cultural identity from outside. The process of identity-building is lifelong; applying to young people as much as the middle-aged and elderly. Scholars use the term 'doing identity' or 'identity work' (Buckingham 2008; Keupp and Höfer 1997) in order to underline the active contribution of the subject in the identity-building process. They argue that the individual adapts his or her identity all the time, depending on different social contexts and communication situations.

Most empirical work on 'doing identity' i.e. active identity formation, has been done in the field of youth studies. For example, youth cultural studies have emphasised the significance of popular music in relation to young people, noting the importance of music both as a cultural resource in the process of identity construction and as source of empowerment. Young people appropriate music in a specific way and use it as a tool to distinguish themselves collectively from other social and ethnic groups (Bennett 2005, p. 119, p. 139). Music-related activities seem to support adolescents in the developmental tasks they are facing in this life phase. In the context of music, lyrics and the musicians, individuals experience themselves and find references to their body, feelings and thoughts (Hoffmann 2009, p. 165). All these aspects become important for the articulation of migrant identity, as well as migrants using music from different contexts; perhaps to reconnect to their roots, to the country where they live or to global popular culture.

Similarly, music becomes important on the collective level of a diaspora. Hepp (2006, p. 285) defines 'diaspora' as a network of an imagined ethnic community, living outside the land they came from permanently and spread over different territories of nation states. It is based on a shared feeling of belonging to this imagined community (Sūna 2017a, b). As Bennett (2005) notes, music generates a sense of shared identity and reinforces the solidarity of the 'people of the diaspora':

The key function of music lies in its ability to readily articulate a collective sense of cultural identity. Inscribed in the musical text are a range of cultural referents which are instantly brought to life through the act of performance, dancing and singing. Participation in this musicalised enactment of collective cultural identities plays a highly important role in the lives of displaced ethnic minority groups. (Bennett 2005, p. 125)

Migration has led diaspora groups to seek ways of relocating themselves culturally in their new surroundings. As agents of cultural identity formation and communitymaking, culture and music are an important part of the collective identity of migrant groups. Migrants appropriate (de Certeau 1988) different frames of reference that are rooted in both national and transnational culture.

Based on empirical data, the following sections discuss different modes of migrant identity formation in the context of a mediatised appropriation of culture. The concept of media appropriation as introduced by Michel de Certeau (1988) describes the practices of integrating media content into the everyday lives of individuals. 


\subsection{The Latvian Diaspora in Germany}

Historically, different migrant groups have been living in Germany since the 1960s. They responded to a German invitation to work in the industries developing after World War Two. Initially invited to work for a period of several years, a large percentage of these so-called gastarbeiter or foreign workers decided to stay in Germany because there was demand for workers for a longer period. The initial migration of gastarbeiter was followed by a second phase, where their families were allowed to join them. As a consequence, large communities of Turks, Italians, Yugoslavs and others developed in Germany. After the collapse of the Soviet Union, a new migration stream from the countries of this region began. Mostly they were ethnic Germans and the so-called 'quota refugees' of Jewish descent from the countries of the former Soviet Union. Within a repatriation programme these people were considered as Germans and invited to return to Germany. They were expected to be 'Germans' and there was no real expectation of cultural differences - which, of course, there were. The migration flows described below have had the effect that in total, currently about $20 \%$ of the inhabitants in Germany have a so-called migration background (if the person or at least one parent does not possess German nationality by birth).

A number of studies have shown that Germany's migrant communities are very heterogeneous, although they have typical migration patterns and media use as well (Dietz 2007; Hepp et al. 2012; Karakasoglu 2007). The focus of this research - the Latvian diaspora in Germany - has not been studied by social scientists until now. The Latvian diaspora in Germany is a rather small and new migrant group. Apart from migration flows from Latvia during World War Two that generated a strong community of exiled Latvians in western Germany, only a few Latvian migrants were able to leave the Soviet Union during the Cold War. Most Latvians came to Germany after the collapse of the Soviet Union and initially only in small numbers, due to the difficulty of getting legal residence status.

According to the official register of residents, there were 38,290 Latvian citizens registered as living in Germany in 2017 (see Fig. 9.1). But if we define the Latvian

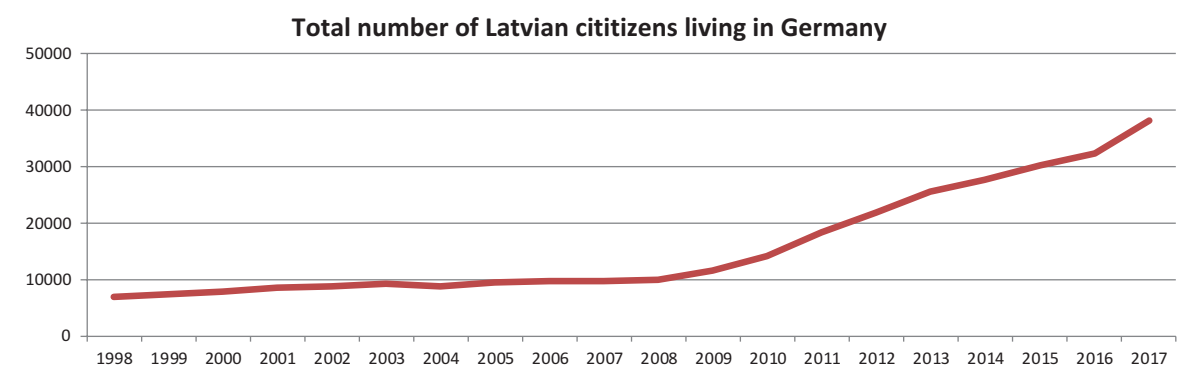

Fig. 9.1 Total number of Latvian citizens living in Germany. (Source: Statistisches Bundesamt 2018, p. 20) 
diaspora a little more broadly as 'people who identify themselves with Latvia and Latvian culture', this figure might be much higher. Included here might be people who have German citizenship now, but still nonetheless feel a strong attachment to Latvia. We must also consider that not all Latvians living in Germany will be officially registered. According to the estimates of experts and Latvian embassy representatives in Germany interviewed for this research, there are about 60,000 Latvians living in Germany - almost a third more than the official figure.

The dynamics over the past quarter century of the numbers of Latvian migrants in Germany reflect the different migration waves. They can be described as three separate and distinct events in Latvia and Europe. The first period followed EU enlargement in 2004, when visa-free movement within the Schengen agreement states was made possible. The second wave can be identified as a consequence of the economic crisis in Latvia in 2008, when unemployment rates in Latvia were the highest in the EU. The third migration wave happened in 2011, when the German labour market was opened to workers from Latvia.

Statistically the average age of Latvian migrants in 2017 was 35 years. According to the data of the German statistical bureau the gender balance was $49 \%$ women, $51 \%$ men (Statistisches Bundesamt 2018, p. 22). The ethnic composition of the Latvian diaspora is heterogeneous and reflects the wider Latvian society. A survey conducted for the project The Emigrant Communities of Latvia in which 1368 respondents from Germany were surveyed, showed that $64 \%$ of migrants from Latvia in Germany describe themselves ethnically as Latvian and 30\% as Russians, while $6 \%$ have a different ethnicity. Out of these respondents, $89 \%$ were Latvian citizens, $6 \%$ were non-citizens or so-called 'aliens' with a Latvian passport but no rights to participate in elections in Latvia, and 5\% had different passports while 9\% had several citizenships.

Regarding their ethnic identity and social context, The Emigrant Communities of Latvia survey showed that the Latvian diaspora in Germany is ethnically rather open, as $39 \%$ had a Latvian partner and 29\% a Russian partner, while $32 \%$ stated that they lived with someone with a different ethnicity; for example, a German partner or someone from another migrant group.

\subsection{Methodology}

The evidence presented in this chapter is generated from the study The Emigrant Communities of Latvia which was carried out from 2014 to 2015. A subsection in this research Transnational Identity of the Latvian Diaspora in Germany focused on the role of culture for the formation of cultural identity as this is seen as an important component of migrant identities. In addition, the project dealt with more general questions on transnational identities of the Latvian diaspora and the role of media in the construction of diasporic identities.

The study is based on media ethnographic research and aims to reconstruct the cultural identity and media appropriation in the subjective perspective of the 
individuals, in order to arrive at a grounded understanding of identity formation processes. The concept of media ethnography is not focused on the 'thick description' (Geertz 1994) of individuals' life-worlds. Media ethnography is understood here as 'an ethnography of people who use, consume, distribute or produce media' (Bachmann and Wittel 2006, p. 183). Accordingly, media ethnography in general does not operate with long-duration stays in one field (Lotz 2000). The current study uses the approach of 'accumulated ethnographic miniatures' (Bachmann and Wittel 2006), understood as the combination of a number of different short stays, observations and interviews in the field. This allows the researcher to make propositions on specific ways of media appropriation and identity development.

All the data for this study on the Latvian diaspora in Germany was collected in two German cities: Berlin and Bremen. With three million inhabitants, Berlin is the capital, and the biggest city in Germany. Bremen has about half a million people. Theoretical sampling as used in grounded theory (Strauss and Corbin 1990) was applied in recruiting and selecting participants in the study. Respondents were selected by the principle of diversity reflecting age, education and gender and duration of residence in Germany. The data collection in interviews proceeded until no new information on the research question was acquired and data saturation was achieved. The sample included 21 Latvians living in Germany, aged between 23 and 52 years old. Seven were men, and 14 were women. The longest period of time spent in Germany was 15 years while the shortest was 1 year. The educational levels included secondary school, vocational education, university bachelor and master degree, and doctoral degree. Three of the participants - Jelena, Olga and Ina - are Latvian-Russians or have Latvian and Russian parents.

Each person was interviewed about their migration experience, identity and media appropriation. They were asked to draw a network map and to keep, as far as it was possible, a 1-week open media diary (Berg and Düvel 2012), i.e. an unstructured record of all the media including content they engaged with in that 7-day period, for example, online news, social media networks, Skype conversations, emails and texts etc. The network maps are free drawings of the person's communicative network, which was explored during the interview. These maps were used in triangulation with the interviews to capture the structures of communicative networks, while the media diaries made it possible to reconstruct the processes of media and cultural appropriation over the week. The whole data was analysed by a coding process oriented to qualitative content analysis (Mayring 2008). The data from the qualitative interviews, network maps and media diaries was coded and analysed in order to identify and describe everyday patterns of media appropriation among Latvian migrants in Germany in relation to dominating forms of cultural identity. The following sections of the paper describe findings that emerged from these 'ethnographic miniatures'. All quotes used from the interviews are anonymised by giving the respondents pseudonyms. The main quotes presented in this chapter are from the interviews. 


\subsection{Findings}

\subsubsection{Mediatised Culture and Identity Building Processes of the Latvian Diaspora in Germany}

According to the research question of this chapter about the role of culture and music for the Latvian diaspora in Germany, the data reveal its importance for forming a hybrid cultural identity. In the following section I will argue firstly that the appropriation of Latvian culture - and in particular, music - confirms and strengthens the self-perception of the Latvian diaspora. It corresponds with the ascribed image of Latvians as a nation that sings. Secondly, appropriation of culture delivers an important link to the country of origin and its discourses of popular culture. Thirdly, Latvian music and culture is an important aspect for the forming and cohesion of the local diaspora community.

\subsubsection{Transnational Identity and Culture}

The individual aspects of the cultural identity of Latvians living in Germany can be described by the analysis of their identification patterns and their integration in the subjective self-image. All the interviewed respondents - including Russian speakers as well - defined themselves as Latvians or as someone who belongs to Latvian territory. 'Latvian-ness' is understood here less as ethnic belonging but rather as belonging to the Latvian state and Latvian culture. This is proved through the example of those individuals who do not have Latvian citizenship but nevertheless define themselves as Latvians. For example, 47-year-old Aivita, a Latvian, has lived in Germany since 1991 and has only German citizenship:

I see myself as a Latvian, there is no doubt about it. If you look at my family history, you see that the nationality is unimportant for me. What importance does it have? I am born in Latvia, I grew up in Latvia.

The quote reflects how respondents understand the concept of belonging to the territory of Latvia. Another respondent, 23-year-old Evija, said that even if she gained German citizenship she would still have a strong identification with Latvia and Latvian culture:

I would not say that at the moment I wish to gain German citizenship. There is a possibility that someday I will be a German citizen. But I will stay Latvian forever. I would not be German. Maybe it would be written in my passport then. But this does not change your identity and that's where you come from.

These examples show a hybridity of identity, where different national cultural references become important. Many of the Latvians interviewed see themselves as wellintegrated in German society and feel a strong commitment to German society. Often spontaneous cultural situations or music appropriation brings 'Latvian-ness' 
to the front of this hybrid identity. These different identity aspects are not exclusive and are well combined in everyday life. In the following interview extract 38-yearold Ina describes it vividly:

\begin{abstract}
Music is a connection with my home country. You are living here, running and working. But when you suddenly hear Latvian folk music on your Walkman, you return to a lost normality. It is related to my inner state. It is important to me. I am what I am. In fact, I am integrated very well here - perfectly, actually. Often, I forget that I am not German. I am not feeling German, but I am also not feeling a stranger, or somebody from outside, or a different individual. But my nature is different. When I listen to my favourite [Latvian] rock opera 'Läčplēsis', I go crazy. This music activates such sounds and veins in me that are hidden under rational layers all the time. And then your other identity comes out that is very deep inside you.
\end{abstract}

The self-perception of Latvians is articulated as people for whom music is important. Evija underlines this with the following sentence: 'Yes, we are a nation that sings.' This co-articulates with the national image the state is developing. Every 5 years a Latvian Song and Dance Festival is organised in which amateur choirs from Latvia and Latvian choirs from all over the world participate, singing mostly Latvian folksongs and classical choir songs. Ina, a highly qualified worker in her late $30 \mathrm{~s}$, describes a typical biographical pattern in this context that is forming the collective discourse about the Latvian nation:

This is how I grew up. I think all Latvians grew up like this. Starting from the first grade you sing in a choir, dance in a folk-dance group, at your Grandma's during your childhood [you sing]. My Latvian Grandma in Skrīveri always sang. She sang folksongs, she recited folksongs, read books to me. So music is in your life from an early age.

Some Latvians interviewed, like Arvis and Uldis, participated in the 2013 Song Festival and continued to sing in local Latvian choirs in Germany. Anita sings in the Latvian choir in Berlin because she 'likes to sing' and she loves Latvian music. Other reported watching clips from the festival on the internet again and again, extending the strong emotions of common culture and identity experienced at the festival. The importance of Latvian music for cultural identity describes the efforts of the diaspora to teach the second generation - their children - traditional Latvian music and culture. Anita and Uldis sent their children to Latvian Sunday school in Berlin. Anita explains her reasons as follows: 'I wanted my daughter to learn Latvian songs - folksongs.' Uldis sings Latvian lullabies to his son and reads Latvian fairy tales. Evita says her children sing popular Latvian songs when they are driving in the car.

If asked about their musical preferences most of the Latvians interviewed in Germany named Latvian pop and folk music as their favourite - besides European and American pop music. Many of them have Latvian music in their record collections; others listen to Latvian music via the internet. Uldis, for example, has listened to Latvian music online 'for several years'. Most of the respondents prefer music that was popular when they still lived in Latvia and can be described as 'pop and rock classics' or as Maiga calls it, 'the good old songs'. 
Sometimes music provokes feelings of nostalgia and homesickness: at other times, Latvian music is an important component in celebrations at festivities.

All interviewees reported feeling nostalgic from time to time. Those who left Latvia recently felt homesick more often. But all Latvians interviewed in this study struggle with this feeling from time to time. Latvian music is used in such situations for solace. As Inese puts it: 'When I miss Latvia, I turn on Latvian music, listen to it and cry a little.' Olga listens to recordings of Latvian choir music. This music gives her a powerful link to her home country. Evija uses Latvian music as a motivator when she is tired and sad:

I listen online to the [choir] song Song of the Soul. It is so emotional. Or I watch some songs from the Song Festival, how the big choir sings the beginning of the song Light Castle. Then you sit there and feel how the Latvian-ness is filling you up. You can move on; you have charged the energy from your home country.

Strong emotional attachment to Latvian culture and the Latvian nation strengthens self-perceptions as 'a Latvian'. Many respondents report that their feelings of national identity and belonging got stronger when they left their home country. Abroad they feel they are 'more Latvian' than they did when living in Latvia before migrating. These feelings get stronger partly because of cultural practices in everyday life. One 43-year-old woman, Vaira, said she learned to value Latvian folklore and culture after she left Latvia to live in Germany:

\footnotetext{
I wanted more traditions, more folklore here. When I was still in Latvia, I was not so much into it. Actually, I found a passion for it here. Many things changed for me here, how I now see them. What Latvia is, how important Latvia is for me: I realised that from a distance. (...) For example the Latvian cultural heritage: the Dainas [folksongs], the poets, the writers are unique in Latvia. I have learned to appreciate Latvia more; all that is associated with Latvia. I have become a bigger Latvian patriot here than if I would be if I still lived in Latvia.
}

Similarly, Evita, 30 at the time of the study, when talking about the celebration of Latvian festivities in Germany remarked: 'I think that the traditions [among Latvians] are pursued more here and are appreciated more than in Latvia.' The celebration of Latvian festivities within the group maintains the collective aspects of a national identity, as will be shown later.

Some respondents show aspects of hybrid identity; that is, different references of a certain identity. They feel a strong connection to such transnational narratives as 'the European idea' and 'German society'. The example of Evija, a 23-year-old bachelor student underlines that. She sees European culture and values as part of her identity and dissociates herself from the older generation in Latvia, for whom - she thinks - the values of the Soviet time are still important:

First of all, I feel myself as a Latvian. A Latvian who lives in Germany, who is maybe in some sense Germanised. Basically, I feel myself as a European. (...) I understand the European world much better. European culture, language and traditions. Rather than the other side, Soviet Union, Russia; I think all that that is closer to my parents. (...) Unfortunately in Latvia there are people who love the Soviet culture. Even if it sounds weird, I belong to Europe. 
Evija's quote underlines the everyday negotiation processes of the different cultural discourses on which that hybrid identity relies. She feels both Latvian and European at the same time and has to combine these two orientations under one concept of cultural identity. However, a European identity is typical only for a few respondents, and this identification is less strong than the identification with Latvia. Here we can see the importance of context in the identity-building processes. Different identity aspects become important depending on the particular context and situation. Different identity references do not exclude each other, but rather are reciprocal. All respondents rely on 'Latvian-ness' with the most important identity reference being a subjective defined Latvian culture. But many speak about the relevance of the German context and European values, as the example of Evija shows. For example, Rudolfs, a 40-year-old who describes himself as being strongly assimilated into German society, says: 'Some [Latvian] national pride is left here. It is not wholly Germanised.' Similarly, Ina, 38, who grew up in a bilingual family, defines herself as Latvian, despite there being Russian culture in her family in Latvia and her feeling that the German aspects of her life are important as well:

Int.: When someone asks, how do you define yourself, who you are?

Resp.: Latvian of course. I am not Russian. I have heard about Russia, I have been there, but I don't feel like... Ok, Russian culture is important for me, I understand it. But German culture is important for me too and I understand it. But I do not feel [that] ... There is no such question.

Int.: Others say they have a double identification.

Resp.: No, I don't have double identification. I am somehow totally clear about it. I don't know, maybe it is because of the Latvian folklore, but for me Latvian bushes are more like home than this flat [in Germany]. I don't know... Latvia is totally different. This goes so far, that when I arrive in Latvia, when I get off the bus, the air, the land, the trees are the same as here, but it feels different. Somehow all these different layers that I have here fall away leaving only one layer that is wild but authentic.

Ina's words describe the plurality of migrant identities and suggest that different identifications - such as in her case, Latvian, Russian and German - are not conflicting and can be lived mostly in a state of harmonic hybridity.

\subsubsection{Connection to Latvia and Different Cultural Discourses}

Most of the Latvian migrants interviewed in this study mentioned the need to be connected to pop-cultural discourses in Latvia and other countries. Those socialised in the former Soviet Union report strong links to Soviet cultural heritage as well. This shows the importance of another identity layer - the Soviet popular cultural layer for Latvian migrants over the age of 35 .

The connection to different cultural discourses is integrated in everyday media use, with a regular appropriation of different Latvian news websites and social network sites. These discourses are important frames of references of migrant identities; of the understanding about Latvia, 'Latvian-ness' and the Latvian diaspora. This is the case for Marija, a 49-year-old unskilled worker, who says: 'Latvian 
culture has been important for me all the time.' To fulfil her cultural interests, she watches Latvian movies which she finds mostly on YouTube:

Lately I have been watching the movie Liktendzirnas [The Mills of Fate, 1997] several times. I love this Latvian movie very much. I love it so much that I can watch it very often. (...) On YouTube you can see many Latvian movies. I watch mostly different popular movies. Like Ezera sonate [Lake Sonata, 1976] for example.

The film Marija mentioned first, The Mills of Fate, was made in the late 1990s and can be seen as a movie representing the national mood of the late twentieth century in Latvian society, where optimism after the restoration of independence is confronted with the economic difficulties of a post-Soviet state. It corresponds with the rather negative attitude of Marija towards the Latvian state: she is 'disappointed' with the economic situation in Latvia. The second film, Lake Sonata, was made in the mid-1970s. This drama pictures a complex intertwining of history with the fate of several members of a single family, unfolding as a heart-breaking love story and showing the way of life in rural Latvia in Soviet times. The preference for this kind of film corresponds to Marija's longing - as she mentioned in the interview - for the 'good old times' of the Soviet Union.

Like Rudolfs, Berlin choir singer Anita describes a regular appropriation of the 'golden classics' of Latvian popular film culture. Anita lists many Latvian cinema and animation films produced during Soviet times which are very popular among Latvian viewers. She says: 'You can watch them all online. Before that we bought DVDs and watched them on weekends and holidays.'

For Latvian migrants over the age of 35, culture from the Soviet era is an inseparable component of Latvian culture and plays an important role in the self-perception of Latvians of a certain age. The regular appropriation of these Soviet-time cultural artefacts defines the national cultural identity of Latvian migrants in Germany.

Watching films made in independent Latvia and also Soviet Latvia is part of the way Anita is teaching Latvian culture and language to her daughter as she grows up in Germany. Ina, for example, says that contemporary Latvian films help her to stay connected with the Latvian language; something she has problems with in her environment, which is mostly German-dominated. Other respondents report similar efforts to teach their children Latvian culture and language. For example, Ingrida, a 41-year-old mother of two, bought her daughter books of Latvian folk song music so she can play these songs on the flute.

Furthermore, a deep interest in cultural news is inter-related with the need to be able to participate in daily conversations with family and friends when connected via media or visiting the home country. For example, Evija tried to catch up on the popular music scene in Latvia as she wanted to be a part of a discourse, not only with her friends but in the wider society as well:

Resp.: I watched the Eurovision Song Contest a little. I wanted to be up to date. Because when I am at home [in Latvia] people are talking about it. My friends are talking about it, but I have no clue about it. Then I watched some videos they posted.

Int.: Which song was the last one you listened to?

Resp.: This new song from the singer Dons called 'Last Letter'. This is a song all Latvia was talking about. I thought: 'What is that song?' It turned out it had been very popular in Latvia for some time already. I got to know it a little late. But better late than never. 
Other respondents use the resources of the Latvian social networking site draugiem. lv, where new songs can be streamed. Rita and Maria sometimes watch the music talent show $O$ Kartes akademija [a TV format similar to American Idol] as they want to be informed about emerging pop stars in Latvia. Sabine and Evita watch popular Latvian soap operas on the internet; the same ones they watched before their emigration. Inese regularly watches the internet show Suņu büda, in which popular people from Latvia are interviewed, similar to the TV show Hard Talk. These are just a few examples of how Latvian popular culture is embedded in global TV culture. Most respondents link this culture to the current Latvian culture and not the current global culture. This shows some possible multi-layering and hybridity of the cultural identity of Latvian migrants in Germany.

The Eurovision Song Contest, a contest in which participants from different European countries are voted by a TV audience as the best music performer in Europe, activates the sense of national belonging to Latvia. It has a re-connecting function. Sabine says, for example, that she started to follow the event only after she left Latvia. She links it with her patriotic feelings and with the interest on popcultural news from Latvia. Her view corresponds with other respondents - that even if they could not attend such events like the Song and Dance Festival or the Eurovision Song Contest, they would follow them online and were thrilled about the achievement of Latvian artists. Similarly, Evita connects popular cultural events with patriotic feelings, which corresponds with views expressed by other respondents. They are proud of the achievement of Latvian artists and athletes in Latvia and abroad. Discussing an ice hockey match between Latvia and Canada at the Winter Olympics in Sochi in 2014 Sabine said: 'Of course I was proud to hear about Latvia [on German media]!' This emphasises the role of the media in giving access to different cultural events. Previous papers (see Sūna 2017), have shown that migrants from Latvia in Germany use four different media spaces - media from Latvia, Germany and Russia, as well as transnational diasporic media. This plurality of information spaces corresponds with the different layers of migrant cultural identities.

Parallel to the mediatised connection to Latvian cultural discourses, some interviewees try to follow cultural news intensively when they are in Latvia, and participate as much as possible in cultural events. This quote from Ina describes this well:

I was at the [outdoor music] Positivus festival in the summer. I feel the need and necessity to experience things that are going on in Latvia. It is not so that I go to home to sit down with my mother and drink coffee and then go back. I want to gad [breathe in] through Latvia; I want to go to the Positivus festival, to participate in all that happens.

The biggest international pop-music festival in Latvia, Positivus is popular among the Latvian middle class, which is already oriented to Western culture and can be described as rather cosmopolitan. Ina's views, quoted above, describe a strong orientation to Western cultural discourses that can be re-connected to the discourses dominant in the German middle class.

For Evita, a 30-year-old housewife, it is important that she and her children go to Latvia at least three times a year and get maximum insight into the current cultural life when they are there. This corresponds with her desire to belong to Latvian society still. She has the feeling that her active engagement with cultural life during her 
visits to Latvia satisfies this desire. This goes hand in hand with her efforts to maintain a Latvian identity and to pass it on to her two children. She says:

Before we go to Latvia, I search for the cultural programme there and consider what we can do together with the children during our visit. When we are there I have a plan: how we can see everything in these two weeks and show our children what's important to us.

Evita's comments show the mediatised preparation work she does on cultural participation in Latvia and her role in providing Latvian culture to her children.

Others, such as Ingrida, try to get overall information on the cultural news and on new cultural products while they are in Latvia:

When I am in Latvia, I have some things I always do: I go to a record store, a book store, and a knitting store. These are things that I have to do. (...) In book stores I look at which new books are released, Latvian mostly. (...) I ordered a new CD recently from the Latvian Song and Dance Festival.

The cultural products which are important for the development of cultural identity vary, from music CDs to Latvian food and clothes. It shows how important a variety of information about everyday practices of cultural appropriation can be for the analysis of cultural identity.

As well as gathering information about cultural activities in Latvia, most Latvian migrants interviewed in Germany see it as important to be informed about other issues too, such as politics and local celebrity life. This is integrated in their everyday media appropriation practices. For example, they read news websites from Latvia almost every day. Vaira, who is originally from Liepaja, a cultural centre in Western Latvia with strong musical traditions, says she seeks out news about the city where she spent her childhood:

I do still read these [Latvian] internet pages. I know what is going on there. I talk to my mother and my sisters. I think it is important for me to know what is going on there. Because if I am a Latvian citizen and I go to the elections then I have to know what they are doing in Latvia. At least via media. I look them up [these websites] every day. These are the usual websites - Apollo, TVnet, Kas jauns? Liepajnieki. Because Liepaja is important for me.

This quote shows Vaira's strong attachment to Latvia and to the particular region she comes from. She also reveals the typical ways migrants source their information about Latvia. On the one hand she reads news websites, while on the other hand she gathers information from mediatised interpersonal communication such as VoiceOver-IP communication or communication on social networking sites. This practice of interpersonal communication is typical mostly for respondents who read less Latvian media. It is evident from the interview material that their opinions about Latvia often reflect the rather one-sided opinion of their social network. For example, Anita has quite negative opinions about the political and economic situation in Latvia which, she explains in her interview, her family shares with her.

All in all, the need of migrants as described above to connect to the different discourses from Latvia corresponds with the need to negotiate the meanings and values of a 'typical Latvian'. This negotiation is an active process which results in the cultural narratives of the Latvian diaspora about the imagined Latvian nation (Anderson 1990). 


\subsubsection{Integration Within the Local Diaspora Community: Strengthening the Belonging}

Regarding collective aspects of cultural identity, the data show a relatively strong identification among Latvian migrants with the transnational Latvian diaspora community and the diaspora community in Germany. According to the definition, a diaspora gets stronger if there is a common narrative and communicative practices that spread it. The need for communication with other Latvians and the need to connect with those nearby confirm that. It is important for Latvian migrants in Germany to celebrate different Latvian festivities like Independence Day on November 18th or the Summer Solstice and Midsummer festivities. The planning and organising of these events is fulfilled via digital media through different but related groups on social media platforms. These common celebrations foster a sense of belonging to the Latvian nation and the common frames of references that are seen as essential for Latvians all over the world. The following quote from the interview with Evija describes this longing to meet other Latvians and confirm her belonging to the Latvian nation:

One Latvian spreads the information about Latvian meetings to others. I was very interested in meeting other Latvians. I thought: 'Somehow I have to celebrate the 18th of November. Somehow, I should show who I am, where I come from.' It was important for me. As well as to find out who these other Latvians are who are living here in Germany.

For Evija, a 23-year-old student, it is important to confirm her patriotic feelings through other members of the Latvian migrant community. Thus, national identity is formed via collective recognition of the peer group and against the background of the German society.

It is typical of new migrants that they are searching for other migrants from their country of origin who live nearby, especially if they have difficulties with the local language. Other members of the diaspora have a supportive function, so new migrants can find their place in their new country of residence. Thus, for the initial period of migration inner-diasporic cohesion is strong, but gets weaker with the integration of migrants into the job market. Some of the Latvians interviewed in Germany accessed the local Latvian community via a Latvian choir, for example. Arvis, 38, who moved to Germany 4 years ago, says:

I wanted to meet our own people. (...) I wanted to meet with Latvians. Especially at the beginning, when you do not know anybody here, then [the choir] is an opportunity to meet other Latvians. But the choir as such is a good thing as I like singing.

In a similar story, Aigars, a 52-year-old unskilled worker talks about seeking contacts in the local diaspora community and finding information about the Latvian choir on the internet. The choir is an important part of the local Latvian community: it unites Latvians with an interest in their culture and delivers a musical accompaniment for Latvian festivities like Midsummer, Christmas, Easter and other celebrations. Here we see how governmental efforts to support the choir culture abroad correspond with the function of community-strengthening in the Latvian diaspora. 
This is true beyond cultural activities, as choir events foster communication among migrants who do not sing by themselves but do attend events like this.

The example of two friends, Ina and Arturs from Bremen, shows that an institutional organisation is not always needed for common cultural practices. Spontaneous groups can emerge based on the common interests and shared values of Latvian traditional and popular culture. Ina and Arturs both sing with their Latvian friends during private gatherings at home on regular basis. Ina describes it in the following way: 'We have a small Latvian group. We come together with guitars and sing. We sing different folksongs. Everybody brings some songs with them. Well, sometimes we sing some Muse or Placebo songs too. Ina's comments show how Latvian music can be a common part of everyday life - i.e. Latvian songs are sung not only at festivities or similar occasions, but are a natural everyday companion. And here again Ina notes that her German friends and acquaintances describe the Latvian community as people who sing Latvian and other songs at parties and confirm their self-perception of Latvians as people who sing, and for whom national culture is an important part of their identification. Also, Ina includes Western mainstream popular music in her musical preferences. This shows again the hybridity of migrant identity, and its ability to unite different national, transnational and global cultural references in cultural identity.

Stories about collective singing or cultural appropriation highlight the aspect of mutual emotional support within the diaspora. This helps migrants develop a sense of belonging to the place of residence. Evija stresses that the diaspora community delivers support in the form of common understanding and cultural proximity that is typical within a nation. As mentioned earlier, most of the respondents feel nostalgia and experience situations where they are not fully understood by German society. Evija describes this cultural proximity via common cultural appropriation practices:

I am always so happy to meet her [her friend, another Latvian girl]. Because it is like she knows the culture where you come from. You can start a song and she can finish it. Or she understands specific jokes that only Latvians understand. That is, in essence, a person who understands you and the culture you come from.

Running alongside local diaspora networks and networking, some of the Latvians interviewed showed close connections with the transnational Latvian diaspora in Europe. This is maintained mostly via mediatised communication, although on this level personal communication is more important than cultural aspects. An exception here is Latvians who are members of institutionalised cultural organisations like choirs or folk-dance groups. They participate in different regional and European cultural events and connect to members of the Latvian diaspora in other countries. For example, Arvis participated in a European choir rehearsal in Brussels and performed at a concert for Independence Day in Hamburg. Again, cultural activities performed transnationally strengthen the collective identity of Latvian migrants.

All in all, culture can be seen as a catalyst for the development of the local diasporic community. Participation in the activities of the diaspora in typical traditional and popular cultural activities fosters connections with the transnational diaspora and generates a sense of transnational belonging to the imagined Latvian nation. 


\subsection{Conclusions}

The aim of this paper was to explore how cultural and media appropriation impact on the identity formation of recent Latvian-origin migrants in Germany. Data analysis in this chapter shows that the local and mediatised appropriation of culture shapes the individual and collective self-perception of Latvians living abroad. Latvian culture is seen as a representation of collective narratives of imagined common frames of references of the Latvian nation. The results showed a plurality of these references as they consist of influences from the period of Soviet Latvia and also Western popular culture. This multi-layeredness reflects in the hybridity of the cultural identities of Latvian migrants that are mostly taken for granted and not seen as problematic.

Many social scientists like Beck (1997) and Welsch (1999) have made the point that music and culture increasingly circulate beyond the confines of the nation-state, and that links between culture and nation are now weakened. According to this view, musical cultures existing within a nation state are rarely exclusively national, as - due to the mediatisation processes - they are shaped by transnational cultural flows. Despite this Hesmondhalgh (2013, pp. 153-157) stresses that musical nationalism is still an important issue in Europe - and that could be shown in this paper as well.

The great importance of ethnic culture and music for migrants can be explained with the concept of 'small nationalisms' (Hall 1995; Hepp 2004; Lull 1995) which is typical of diasporas. Small nationalisms can be described as efforts to reterritorialise the culture of the origin nation abroad. The appropriation of culture, discussed in this paper, confirms these efforts. The efforts of the Latvian diaspora in Germany in still trying to maintain a common Latvian culture is an example of small nationalism. With the help of ethnic music and culture they identify with a collective cultural narrative of the imagined nation. Through these cultural references distinction processes become active as these deliver a common understanding of belonging, distinction and otherness. Music confirms the reported selfperception of a national identity that is then negotiated with others in communication processes.

On one hand, as this paper has shown through the examples of the cultural activity of members of the Latvian diaspora in Germany, culture and popular music is associated with abstract national values. Georgiou (2012) describes it as the development of cultural proximity via the appropriation of culture from the country of origin.

On the other hand, music - especially Western mainstream popular music - can mediate cross-culturally between different nations and nation states. Musical experiences help to make connections with others, both within and outside the diaspora. However, whether musical experiences might breed commonality across differences cannot be addressed with one simple answer. 
Therefore, the advent of the internet and online communities has enabled the building and strengthening of émigré Latvian communities linked to friends, family and culture back in their country of origin, mobilising especially at times of national celebration or festivities, such as Independence Day, New Year or name days. It is the hybridity of identity that makes this cultural nationalism possible. The transnational Latvian identity can exist parallel to the well-integrated migrant identity. They do not exclude each other: Alongside their interest in Latvian culture, all respondents showed at least a little interest in the country they were living in as well as other Western European cultural fields. All in all, this chapter revealed the hybridity of Latvian migrant identities and it could not confirm fears in German public discourse about alienation within migrant communities. It showed that belonging to the imagined Latvian nation is an important part of migrant cultural identity but does not result in isolation in the county of residence: rather, it is combined in a lived hybridity. It can be assumed that the dynamics of cultural and media identity described can also be observed among Latvian migrants in other countries.

\section{References}

Akşen, B. (2013). Mediatisierte Partizipationsgenerationen. Medienpartizipation und IKTBerufspartizipation türkischer Migrationsgenerationen. Hamburg: Verlag Dr. Kovac.

Anderson, B. (1990). Imagined communities. London: Verso.

Bachmann, G., \& Wittel, A. (2006). Medienethnografie. In R. Ayaß \& J. Bergmann (Eds.), Qualitative Methoden der Medienforschung (pp. 183-219). Reinbeck b. Hamburg: Rowohlt.

Beck, U. (1986). Risikogesellschaft. Auf dem Weg in eine andere Moderne. Franfurt am Main: Suhrkamp Verlag.

Beck, U. (1997). Was ist Globalisierung? Irrtümer des Globalismus-Antworten aufGlobalisierung. Frankfurt am Main: Suhrkamp Verlag.

Bennett, A. (2005). Culture and everyday life. London: Sage.

Berg, M., \& Düvel, C. (2012). Qualitative media diaries: An instrument for doing research from a mobile media ethnographic perspective. Interactions: Studies in Communication \& Culture, 3(1), 71-89.

Bozdağ, C. (2013). Aneignung von Diasporawebseites. Wiesbaden: Springer VS.

Buckingham, D. (2008). Introducing identity. In D. Buckingham (Ed.), Youth, identity and digital media (pp. 1-24). Cambridge, MA: The MIT Press.

de Certeau, M. (1988). Kunst des Handelns. Berlin: Merve-Verlag.

Dietz, B. (2007). Aussiedler/Spätaussiedler in Deutschland seit 1950. In K. J. Bade, P. C. Emmer, \& L. Lucassen (Eds.), Enzyklopädie Migration in Europa (pp. 397-404). München: Fink.

Geertz, C. (1994). Thick description: Toward an interpretive theory of culture. In M. Michael \& L. McIntyre (Eds.), Readings in the philosophy of social science (pp. 213-231). Cambridge, MA: The MIT Press.

Georgiou, M. (2012). Watching soap opera in the diaspora: Cultural proximity or critical proximity? Ethnic and Racial Studies, 35(5), 868-887. 
Hall, S. (1994). Rassismus und kulturelle Identität. Ausgewählte Schriften 2. Hamburg: Argument Verlag.

Hall, S. (1995). Kultur. Community. Nation. In C. Harzig \& L. Back (Eds.), Widersprüche des Multikulturalismus (pp. 26-42). Hamburg: Argument-Verlag.

Hepp, A. (2004). Netzwerke der Medien. Medienkultur und Globalisierung. Wiesbaden: VS Verlag für Sozialwissenschaften.

Hepp, A. (2006). Transkulturelle Kommunikation. Konstanz: UVK (UTB).

Hepp, A. (2015). Transcultural communication. Hoboken: Whiley Blackwell.

Hepp, A., Bozdag, C., \& Sūna, L. (2012). Mediatized migrants: Media cultures and communicative networking in the diaspora. In L. Fortunati, R. Pertierra, \& J. Vincent (Eds.), Migrations, diaspora, and information technology in global societies (pp. 172-188). New York: Routledge.

Hesmondhalgh, D. (2013). Why music matters. Hoboken: Wiley-Blackwell.

Hitzler, R., \& Niederbacher, A. (2010). Leben in Szenen. Juvenile Kulturen unter den Bedingungen der Spätmoderne. Wiesbaden: VS Verlag für Sozialwissenschaften.

Hjarvard, S. (2008). The mediatization of society. A theory of the media as agents of social and cultural change. Nordicom Review, 29(2), 105-134.

Hoffmann, D. (2009). "My music pulls me through" - Musik als identitäts- und sinnstiftende Größe. In H. Theunert (Ed.), Jugend - Medien - Identität. Identitätsarbeit Jugendlicher mit und in Medien (pp. 159-174). München: Kopäd.

Hugger, K.-U. (2007). Verortung der Ortslosigkeit. Hybride Identität, Jugend und Internet. In D. Villányi, M. D. Witte, \& U. Sander (Eds.), Globale Jugend und Jugendkulturen. Aufwachsen im Zeitalter der Globalisierung (pp. 173-184). Weinheim: Juventa-Verlag.

Karakasoglu, Y. (2007). Türkische Arbeitswanderer in West-, Mittel- und Nordeuropa seit Mitte der 1950er Jahre. In K. J. Bade, P. C. Emmer, \& L. Lucassen (Eds.), Enzyklopädie Migration in Europa (pp. 1054-1061). München: Fink.

Keupp, H., \& Höfer, R. (Eds.). (1997). Identitätsarbeit heute. Klassische und aktuelle perspektiven der Identitätsforschung. Frankfurt am Main: Suhrkamp Verlag.

Krotz, F. (2003). Medien als Ressource der Konstitution von Identität. Eine konzeptionelle Klärung auf der Basis des symbolischen Interaktionismus. In C. Winter, T. Thomas, \& A. Hepp (Eds.), Medienidentitäten. Identität im Kontext von Globalisierung und Medienkultur (pp. 27-48). Köln: Herbert von Halem Verlag.

Lotz, A. (2000). Assessing qualitative television audience research: Incorporating feminist and anthropological theoretical innovation. Communication Theory, 10, 447-467.

Lull, J. (1995). Media, communication, culture. A global approach. New York: Columbia University Press.

Mayring, P. (2008). Die Praxis der qualitativen Inhaltsanalyse. Weinheim: Beltz.

Statistisches Bundesamt. (2018). Bevölkerung und Erwerbstätigkeit. Ausländische Bevölkerung. Ergebnisse des Ausländerzentralregisters. https://www.destatis.de/DE/Publikationen/ Thematisch/Bevoelkerung/MigrationIntegration/AuslaendBevoelkerung.html. Accessed 28 Nov 2018.

Strauss, A., \& Corbin, J. (1990). Basics of qualitative research. Grounded theory procedures and techniques. Newburg Park: Sage.

Sūna, L. (2013). Medienidentitäten und geteilte Kultur. Vermittlungspotenzial von Populärkultur für lettisch- und russischsprachige Jugendliche. Wiesbaden: Springer VS Verlag.

Sūna, L. (2017a). Transnationale Identitäten der Diaspora: Die Medienaneigunung politischer Konflikte durch die lettische Diaspora in Deutschland. In O. Jandura, M. Wendelin, M. Adolf, \& J. Wimmer (Eds.), Integration und Diversifikation. Medien und gesellschaftlicher Zusammenhalt im digitalen Zeitalter (pp. 139-154). Wiesbaden: Springer VS.

Sūna, L. (2017b). Theoretische Überlegungen zur Herstellung von Zugehörigkeit und kultureller Nähe durch die Aneignung kultureller Medieninhalte bei älteren Migrant/-innen. Medien \& Altern. Zeitschrift für Forschung und Praxis, 11, 67-74.

Tisenkopfs, T., Daugavietis, J., Lāce, I., Sūna, L., Locika, K., \& Grundšteine, L. (2008). Dziesmu un deju svētki main̄igà sociālā vidē [Song and dance festival in a changing social environment]. Riga: LU SPPI. 
Vogelgesang, W. (2006). Kulturelle und mediale Praxisformen Jugendlicher. In A. Hepp \& R. Winter (Eds.), Kultur - Medien - Macht. Cultural Studies und Medienanalyse (pp. 439454). Wiesbaden: VS Verlag für Sozialwissenschaften.

Welsch, W. (1999). Transculturality: The puzzling form of cultures today. In M. Featherstone \& S. Lash (Eds.), Spaces of culture. City, nation, world (pp. 194-213). London: Sage.

Open Access This chapter is licensed under the terms of the Creative Commons Attribution 4.0 International License (http://creativecommons.org/licenses/by/4.0/), which permits use, sharing, adaptation, distribution and reproduction in any medium or format, as long as you give appropriate credit to the original author(s) and the source, provide a link to the Creative Commons licence and indicate if changes were made.

The images or other third party material in this chapter are included in the chapter's Creative Commons licence, unless indicated otherwise in a credit line to the material. If material is not included in the chapter's Creative Commons licence and your intended use is not permitted by statutory regulation or exceeds the permitted use, you will need to obtain permission directly from the copyright holder.

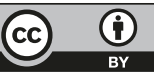

